\title{
Pengaruh pemberian asi eksklusif dan non eksklusif terhadap mental emosional anak usia 3-4 tahun
}

\author{
Any Setyarini ${ }^{1}$, Maria Mexitalia ${ }^{2}$, Ani Margawati ${ }^{2}$
}

\begin{abstract}
Background: Breastmilk is the best food contains all the elements of required nutrients for infant aged 0-6 months, and the attachment of the breastfeeding process give better of growth and mental emotional development of the infant. Less attachment between mother and infant caused mental emotional disorders, that affect to the next period of child's development.

Objective : The objective of this research was to analyze the differences of influence of exclusive breastfeeding and non exclusive brestfeeding history on child's emotional mental age of 3-4 years as well as analyze the most dominant variables.

Method: This was an observational analitic research with cross sectional approach. The subjects consisted of 84 children aged 3-4 years, living Banyumanik subdistrict Semarang, taken by purposive sampling and grouped into exclusive and non-exclusive breastfeeding. The data was collected by questionnaire, and the analysis using chi square and logistic regression.

Result: The study showed that most of children with exclusively breastfed had good mental emotional (76.2\%), while children who did not get exclusively breastfed had a mental emotional problem (64.3\%). There were relations between breastfeeding $(p=0,001)$, mother's knowledge ( $p=0,001)$, mother's attitude $(p=0,001)$, and mother's education level ( $p=0,029)$ to children's mental emotional. Education level of mother was the most influence variable for child's emotional mental after addjusted with mother's knowledge, mother's attitude, mother's education level, and birth weight of children.

Conclusion: Breastfeeding history, mother's knowledge, mother's attitude, and mother's education level were factors that influencing to children's mental emotional
\end{abstract}

Key words : exclusive breasfeeding; children; mental emotional disorder

\section{ABSTRAK}

Latar belakang : Air Susu Ibu (ASI) merupakan makanan terbaik yang mengandung semua unsur zat gizi yang dibutuhkan bayi usia 0-6 bulan. ASI dapat mempengaruhi tumbuh kembang bayi, termasuk perkembangan mental emosional melalui kelekatan yang terbentuk lewat menyusui. Kelekatan yang kurang antara ibu dan bayi dapat menyebabkan timbulnya gangguan mental emosional yang berpengaruh terhadap perkembangan anak pada tahap selanjutnya.

Tujuan : Penelitian ini bertujuan menganalisis pengaruh pemberian ASI eksklusif dan non eksklusif terhadap mental emosional anak usia 3-4 tahun serta menganalisis variabel yang paling dominan berpengaruh terhadap mental emosional anak usia 3-4 tahun.

Metode : Jenis penelitian ini adalah observasional analitik, dengan pendekatan cross sectional. Subjek sebanyak 84 anak usia 3-4 tahun yang berada di wilayah kerja puskesmas Kecamatan Banyumanik Semarang, diambil dengan metode purposive sampling dan dikelompokkan berdasarkan konsumsi ASI anak, ASI eksklusif dan ASI non eksklusif. Data penelitian diperoleh melalui wawancara dengan ibu responden menggunakan kuesioner pemberian ASI dan kuesioner skrining masalah mental mental emosional anak menggunakan SDQ (Strenght and difficulties quotionnare). Analisis data menggunakan uji Chi-Square dan regresi logistik.

Hasil : Hasil penelitian menunjukkan bahwa anak yang mengkonsumsi ASI eksklusif sebagian besar (76,2\%) tidak memiliki masalah mental emosional, sedangkan anak yang tidak mengkonsumsi ASI eksklusif cenderung memiliki masalah mental emosional (64,3\%). Ada hubungan riwayat pemberian ASI ( $p=0,001)$, pengetahuan ibu $(p=0,001)$, sikap ibu ( $p=0,001)$ dan tingkat pendidikan ibu $(p=0,029)$ terhadap mental emosional anak. Riwayat pemberian ASI merupakan variabel yang paling berpengaruh terhadap mental emosional anak setelah dikontrol oleh pengetahuan ibu, sikap ibu, tingkat pendidikan ibu, dan berat badan lahir anak.

Simpulan : Riwayat pemberian ASI, pengetahuan ibu, sikap ibu, dan tingkat pendidikan ibu merupakan faktor yang berpengaruh terhadap mental emosional anak.

Kata kunci : asi; anak; mental emosional

\section{PENDAHULUAN}

Air Susu Ibu (ASI) merupakan makanan terbaik yang mengandung semua unsur zat gizi yang dibutuhkan bayi usia 0-6 bulan. ASI juga mengandung zat kekebalan yang akan melindungi bayi dari berbagai

\footnotetext{
${ }^{1}$ SD Islam Pangeran Diponegoro Semarang

${ }^{2}$ Fakultas Kedokteran Universitas Diponegoro
}

penyakit infeksi, bakteri, virus, parasit, dan jamur ${ }^{1,2,3}$ ASI dapat mempengaruhitumbuh kembang bayi, termasuk perkembangan mental emosional melalui kelekatan yang terbentuk lewat menyusui. Kondisi mental emosional pada usia dini dapat mempengaruhi periode perkembangan anak pada tahap selanjutnya. Anak dengan mental emosional yang baik pada usia dini akan mengalami perkembangan yang positif pada tahap berikutnya, dan pada akhirnya mereka akan 
menjadi generasi penerus bangsa yang sehat secara mental emosional. ${ }^{4,5,6}$ Sebaliknya, anak usia dini yang terganggu perkembangan mental emosionalnya merupakan tanda awal kejahatan pada usia remaja seperti konsumsi alkohol, kecanduan nikotin, penyalahgunaan zat, pelanggaran hukum, dan perilaku seks bebas. ${ }^{7,8}$

Angka kejadian gangguan mental emosional yang selama ini dilaporkan di Indonesia melalui kegiatan Riset Kesehatan Dasar (Riskesdas) adalah angka gangguan mental emosional pada usia $\geq 15$ tahun. ${ }^{9}$ Kenyataan yang terjadi saat ini, tanda-tanda munculnya gangguan mental emosional, seperti : memiliki perilaku antisosial, lebih agresif, dan memiliki hubungan yang buruk dengan teman, mulai terjadi pada usia Sekolah Dasar (SD). Komisi Perlindungan Anak Indonesia (KPAI) menyatakan bahwa angka kriminalitas yang dilakukan anak usia sekolah (SD hingga SMA) cenderung meningkat setiap tahunnya.Tindakan kriminal yang dilakukan meliputi pencurian, tawuran, dan pelecehan seksual. ${ }^{10,11}$

Terdapat keterkaitan antara lamanya pemberian ASI eksklusif dengan kejadian gangguan mental emosional. Penelitian Kramer, Fombonne, et al menunjukkan bahwa remaja yang disusui sedikitnya selama 4 bulan memiliki risiko yang rendah untuk mengkonsumsi narkoba dan mengalami gangguan mental emosional.Sebuah observasi yang dilakukan oleh Niles Newton pada tahun 2008 menunjukkan bahwa anak yang memperoleh ASI secara eksklusif selama 6 bulan mempunyai sikap lebih ramah, pandai bersosialisasi dan menunjukkan perkembangan yang lebih baik dibandingkan dengan anak yang mengkonsumsi susu formula sejak lahir. ${ }^{12}$

Kecamatan Banyumanik merupakan salah satu kecamatan yang termasuk wilayah perkotaan di Semarang dan dibina oleh 4 Puskesmas. Cakupan ASI eksklusif di 4 Puskesmas pada tahun 2010 dan 2011 masih tergolong rendah yaitu berkisar antara $0,91 \%$ $29,28 \%$. Kegiatan deteksi dini terhadap masalah mental emosional pada anak usia dini di Kecamatan Banyumanik belum pernah dilakukan meskipun terdapat data cakupan ASI yang rendah 2010 dan 2011 tergolong rendah..$^{13,14}$

Berdasarkan latar belakang di atas maka perlu kiranya dilakukan studi tentang mental emosional anak usia dini berdasarkan riwayat pemberian ASI. Tujuan penelitian ini yaitu menganalisis pengaruh pemberian ASI eksklusif dan non eksklusif terhadap mental emosional anak usia 3-4 tahun dan menganalisis faktor yang paling dominan berpengaruh terhadap mental emosional anak usia 3-4 tahun di Kecamatan Banyumanik Kota Semarang.

\section{BAHAN DAN METODE}

Jenis penelitian ini adalah observasional analitik, dengan pendekatan cross sectional dengan menelaah pengaruh pemberian ASI (eksklusif atau non eksklusif, pengetahuan ibu, sikap ibu, tingkat pendidikan ibu, status ibu bekerja, umur kehamilan, berat bayi lahir, dan IMD) terhadap mental emosional anak. Penelitian ini dilaksanakan dari bulan September sampai Nopember 2013 di 4 Puskesmas Kecamatan Banyumnaik yaitu : Puskesmas Pudak Payung, Puskesmas Ngesrep, Puskesmas Padangsari, dan Puskesmas Srondol. Populasi dalam penelitian ini adalah seluruh anak usia 3-4 tahun yang ada di Kecamatan Banyumanik.

Pengambilan sampel pada penelitian ini dipilih dengan metode purposif sampling. Sampel diperoleh berdasarkan data dari kader Posyandu yang telah ditunjuk oleh pihak Puskesmas dan dilakukan wawancara tentang riwayat pemberian ASI responden. Sampel penelitian yang dipakai sebanyak 84 anakyang dikelompokkan menjadi 2 yaitu : anak yang mengkonsumsi ASI eksklusif dan anak yang tidak mengkonsumsi ASI eksklusif. Jumlah sampel minimal pada masing-masing kelompok sampel adalah 42 sampel.

Instrumen penelitian yang digunakan dalam pengumpulan data yaitu : kuesioner pemberian ASI yang meliputi : berat bayi lahir, umur kehamilan, pendidikan ibu, status ibu bekerja, pengetahuan dan sikap ibu serta IMD dan kuesioner skrining masalah mental mental emosional anak menggunakan $S D Q$ (Strenght and difficulties quotionnare).

Uji normalitas data menggunakan uji Kolmogorov Smirnov. Semua data pada masingmasing kelompok sampel berdistribusi tidak normal $(\mathrm{p}<0,05)$. Analisis data menggunakan uji beda antara dua kelompok yang diteliti dengan uji chi square $\left(X^{2}\right.$ ).Perbedaan dianggap bermakna jika nilai $\mathrm{p}<0,05$ dan regresi logistik biner dengan tujuan untuk melihat pengaruh beberapa variabel bebas (independent) terhadap varibel terikat (dependent). Regresi logistik biner digunakan karena skala variabelnya nominal binomial.

\section{HASIL}

\section{Karakteristik Responden}

Hasil penelitian menunjukkan kelompok responden yang mengkonsumsi ASI eksklusif, mayoritas responden lahir dengan berat badan normal $(95,2 \%)$, lahir pada umur kehamilan $\geq 38$ minggu $(95,2 \%)$, mengalami IMD $(59,6 \%)$, nilai pengetahuan ibu tentang ASI $\geq$ rerata $(73,8 \%)$, nilai sikap ibu terhadap ASI $\geq$ rerata $(71,4 \%)$, tingkat pendidikan ibu tinggi (81\%), ibu 
responden tidak bekerja $(81,0 \%)$, dan anak cenderung tidak mengalami masalah mental emosional (76,2\%). Responden pada kelompok ASI non eksklusif mayoritas juga lahir dengan berat badan normal $(88,1 \%)$, lahir pada umur kehamilan $\geq 38$ minggu (90,5\%), pendidikan ibu tergolong tinggi $(66,7 \%)$, dan status ibu mayoritas juga tidak bekerja (64,3\%). Responden kelompok ASI non eksklusif mayoritas tidak mengalami IMD $(81,0 \%)$, nilai pengetahuan ibu tentang ASI $<$ Rerata $(69,0 \%)$, nilai sikap ibu terhadap ASI $<$ Rerata $(66,7 \%)$, dan mayoritas responden ada masalah mental emosional (64,3\%). Hasil selengkapnya dapat dilihat pada tabel 1 .

Tabel 1. Distribusi Frekuensi Karakteristik Responden Kelompok ASI eksklusif dan ASI Non Eksklusif

\begin{tabular}{|c|c|c|c|c|}
\hline \multirow[t]{3}{*}{ Karakteristik Responden } & \multicolumn{4}{|c|}{ Riwayat Pemberian ASI } \\
\hline & \multicolumn{2}{|c|}{ Non Eksklusif } & \multicolumn{2}{|c|}{ Eksklusif } \\
\hline & $\mathbf{F}$ & $\%$ & $\mathbf{F}$ & $\%$ \\
\hline \multicolumn{5}{|l|}{ Berat Badan Lahir } \\
\hline$<2500 \mathrm{gr}$ & 5 & 11,9 & 2 & 4,8 \\
\hline$\geq 2500 \mathrm{gr}$ & 37 & 88,1 & 40 & 95,2 \\
\hline Total & 42 & 100 & 42 & 100 \\
\hline \multicolumn{5}{|l|}{ Umur kehamilan } \\
\hline$<38$ minggu & 4 & 9,5 & 2 & 4,8 \\
\hline$\geq 38$ minggu & 38 & 90,5 & 40 & 95,2 \\
\hline Total & 42 & 100 & 42 & 100 \\
\hline \multicolumn{5}{|l|}{ IMD } \\
\hline Mengalami IMD & 8 & 19,0 & 25 & 59,6 \\
\hline Tidak mengalami IMD & 34 & 81,0 & 17 & 40,4 \\
\hline Total & 42 & 100 & 42 & 100 \\
\hline \multicolumn{5}{|l|}{ Pengetahuan Ibu Tentang ASI } \\
\hline$<$ Rerata & 29 & 69,0 & 11 & 26,2 \\
\hline$\geq$ Rerata & 13 & 31,0 & 31 & 73,8 \\
\hline Total & 42 & 100 & 42 & 100 \\
\hline \multicolumn{5}{|l|}{ Sikap Ibu Tentang ASI } \\
\hline$<$ Rerata & 28 & 66,7 & 12 & 28,6 \\
\hline$\geq$ Rerata & 14 & 33,3 & 30 & 71,4 \\
\hline Total & 42 & 100 & 42 & 100 \\
\hline
\end{tabular}

2. Pengaruh Pemberian ASI Terhadap Mental Emosional Anak

Uji bivariat menunjukkan bahwa ada hubungan pemberian ASI $(\mathrm{p}=0,001$.$) , pengetahuan ibu$ $(\mathrm{p}=0,001)$, sikap ibu $(\mathrm{p}=0,001)$ dan tingkat pendidikan ibu $(\mathrm{p}=0,029)$ terhadap mental emosional anak. Pemberian ASI merupakan variabel yang paling dominan berpengaruh terhadap mental emosional anak setelah dikontrol oleh variabel pengetahuan ibu, sikap ibu, tingkat pendidikan, dan berat badan lahir anak. Hasil selengkapnya dapat dilihat pada tabel 2 dan 3.

Tabel 2. Pengaruh Riwayat Pemberian ASI Eksklusif dan ASI Non Eksklusif Terhadap Mental Emosional Anak

\begin{tabular}{|c|c|c|c|c|c|}
\hline \multirow[b]{2}{*}{ Kelompok Sampel } & \multicolumn{2}{|c|}{ Mental Emosional } & \multirow[b]{2}{*}{ OR } & \multirow[b]{2}{*}{$\underset{95 \%}{\text { CI }}$} & \multirow[b]{2}{*}{ Nilai $p$} \\
\hline & $\begin{array}{c}\text { Ada } \\
\text { Masalah }\end{array}$ & $\begin{array}{c}\text { Tidak Ada } \\
\text { Masalah }\end{array}$ & & & \\
\hline \multicolumn{6}{|l|}{ Pemberian ASI } \\
\hline ASI Non Eksklusif & $27(64,3 \%)$ & $15(35,7 \%)$ & 5.76 & $2,228-14,894$ & 0,001 \\
\hline ASI Eksklusif & $10(23,8 \%)$ & $32(76,2 \%)$ & & & \\
\hline \multicolumn{6}{|l|}{ Pengetahuan Ibu } \\
\hline $\begin{array}{l}<\text { Rerata } \\
\geq \text { Rerata }\end{array}$ & $\begin{array}{l}26(65 \%) \\
11(25 \%)\end{array}$ & $\begin{array}{l}14(35 \%) \\
33(75 \%)\end{array}$ & 5,571 & $2,172-14,294$ & 0,001 \\
\hline
\end{tabular}




\begin{tabular}{|c|c|c|c|c|c|}
\hline $\begin{array}{l}\text { Sikap Ibu } \\
<\text { Rerata } \\
\geq \text { Rerata }\end{array}$ & $\begin{array}{l}25(62,5 \%) \\
12(27,3 \%)\end{array}$ & $\begin{array}{l}15(37,5 \%) \\
32(72,7 \%)\end{array}$ & 4,444 & $1,768-11,174$ & 0,001 \\
\hline $\begin{array}{l}\text { Tingkat } \\
\text { Pendidikan Ibu } \\
\text { Rendah } \\
\text { Tinggi }\end{array}$ & $\begin{array}{l}14(63,6 \%) \\
23(37,1 \%)\end{array}$ & $\begin{array}{c}8(36,4 \%) \\
39(62,9 \%)\end{array}$ & 2,967 & $1,081-8,147$ & 0,029 \\
\hline $\begin{array}{l}\text { Berat Badan } \\
\text { Lahir } \\
<2500 \mathrm{gr} \\
\geq 2500 \mathrm{gr}\end{array}$ & $\begin{array}{c}5(71,4 \%) \\
32(41,6 \%)\end{array}$ & $\begin{array}{c}2(28,6 \%) \\
45(58,4 \%)\end{array}$ & 3,516 & $0.641-19,269$ & 0,130 \\
\hline $\begin{array}{l}\text { Status Ibu } \\
\text { Bekerja } \\
\text { Bekerja } \\
\text { Tidak bekerja }\end{array}$ & $\begin{array}{c}8(34,8 \%) \\
29(47,5 \%)\end{array}$ & $\begin{array}{l}15(65,2 \%) \\
32(52,5 \%)\end{array}$ & 0,589 & $0,218-1,591$ & 0,211 \\
\hline $\begin{array}{l}\text { IMD } \\
\text { Tidak mengalami } \\
\text { IMD } \\
\text { Mengalami IMD }\end{array}$ & $\begin{array}{l}25(49,0 \%) \\
12(36,4 \%)\end{array}$ & $\begin{array}{l}26(51,0 \%) \\
21(63,6 \%)\end{array}$ & 1,683 & $0,686-4,126$ & 0,180 \\
\hline $\begin{array}{l}\text { Umur Kehamilar } \\
<38 \text { minggu } \\
\geq 38 \text { minggu }\end{array}$ & $\begin{array}{c}4(47,5 \%) \\
33(42,3 \%)\end{array}$ & $\begin{array}{c}2(52,5 \%) \\
45(57,7 \%)\end{array}$ & 2,727 & $0,471-15,768$ & 0,232 \\
\hline
\end{tabular}

Tabel 3. Model Akhir Pengaruh Riwayat Pemberian ASI Eksklusif Terhadap Mental Emosional Anak

\begin{tabular}{lcccccc}
\hline \multirow{2}{*}{ Variabel } & B & S.E. & Sig. & Exp $(\mathbf{B})$ & \multicolumn{2}{c}{$\mathbf{9 5 \%}$ CI for EXP(B) } \\
\cline { 6 - 7 } & & & & & Lower & Upper \\
\hline Pemberian ASI & 1,296 & 0,531 & 0,015 & 3,654 & 1,291 & 10,340 \\
Pengetahuan Ibu & 0,904 & 0,695 & 0,193 & 2,469 & 0,632 & 9,638 \\
Tk_Pendidikan & 0,614 & 0,609 & 0,313 & 1,848 & 0,561 & 6,092 \\
Berat Badan Lahir & 0,603 & 0,956 & 0,528 & 1,828 & 0,281 & 11,896 \\
Sikap Ibu & 0,261 & 0,704 & 0,711 & 1,298 & 0,326 & 5,159 \\
Constant & $-1,965$ & 1,020 & 0,054 & 0,140 & & \\
\hline
\end{tabular}

\section{PEMBAHASAN}

Menyusu akan membuat bayi merasa lekat dan aman. Rasa aman yang dimiliki bayi pada tahun pertama dan kedua kehidupan akan mempengaruhi perkembangan tahap selanjutnya termasuk perkembangan mental emosional anak ${ }^{6,15,16}$ Penelitian yang dilakukan Carlson, Sroufe, et al pada tahun 2004 diperoleh hasil bahwa bayi yang memiliki kelekatan yang baik akan menjadi lebih kompeten secara emosional pada usia 4 tahun dibandingkan bayi lain yang memiliki kelekatan kurang baik. ${ }^{6}$ Penelitian lain dilakukan oleh Kramer et al pada tahun 2008 menunjukkan bahwa remaja yang disusui sedikitnya selama 4 bulan memiliki risiko yang rendah untuk mengkonsumsi narkoba dan mengalami gangguan mental emosional.Studi lainnya di Denmark diperoleh hasil bahwa terdapat hubungan antara penyapihan dini (2 minggu setelah kelahiran) dengan konsumsi alkohol dini pada pria dewasa. ${ }^{12}$

Pengetahuan ibu tentang ASI dapat mempengaruhi mental emosinal anak. Pengetahuan akan mempengaruhi tindakan seseorang termasuk tindakan untuk menyusui. Penelitian yang dilakukan oleh Fauzie pada tahun 2006 diperoleh hasil bahwa sebanyak $63 \%$ ibu yang pengetahuan tentang ASI tergolong baik, berhasil memberikan ASI eksklusif pada anaknya. ${ }^{17}$ Ibu yang memiliki pengetahuan yang 
baik berpeluang 2,75 kali untuk memberikan ASI secara eksklusif pada anaknya dibandingkan dengan ibu yang pengetahuannnya kurang. Variabel sikap juga mempengaruhi ibu dalam pemberian ASI eksklusif. Ibu yang memiliki sikap baik terhadap ASI berpeluang 2,3 kali menyusui secara eksklusif dibandingkan dengan ibu yang bersikap negatif. ${ }^{18}$

Pendidikan ibu juga berkaitan erat dengan pemberian ASI eksklusif. Ibu responden yang berpendidikan tinggi mayoritas anaknya tidak mengalami masalah mental emosional $(62,9)$, sebaliknya ibu responden yang tergolong berpendidikan rendah, anaknya mayoritas mengalami masalah mental emosional (63,6\%). Semakin tinggi tingkat pendidikan seseorang maka semakin matang seseorang akan mengambil sebuah keputusan. ${ }^{19}$ Hasil penelitian Ida pada tahun 2012 diperoleh hasil bahwa proporsi ibu yang berhasil menyelesaikan pendidikan setingkat SMA untuk memberikan ASI eksklusif lebih besar $(28,7 \%)$ dibandingkan dengan ibu yang hanya menyelesaikan pendidikan setingkat SMP $(20,3 \%) .{ }^{20} \mathrm{Ibu}$ dengan pengetahuan dan sikap yang baik dan tergolong berpendidikan tinggi mempunyai pengaruh terhadap pemberian ASI eksklusif. Pemberian ASI eksklusif akan menimbulkan kelekatan ibu dan anak dan dapat berpengaruh terhadap mental emosional anak.

Status ibu bekerja tidak mempengaruhi mental emosional anak karena ibu masih memungkinkan untuk memberikan ASI secara eksklusif. Salah satu faktor yang berpengaruh terhadap keberhasilan pemberian ASI eksklusif pada ibu bekerja yaitu dukungan yang diberikan oleh pimpinan tempat kerja kepada ibu untuk dapat menyusui secara eksklusif. Dukungan pimpinan pada ibu menyusui dapat berupa pemberian jam kerja yang fleksibel, beban kerja yang lebih ringan, dan tidak menugaskan yang bersangkutan ke luar kota selama beberapa hari. ${ }^{21}$ Masalah mental emosional pada anak dengan ibu bekerja terjadi karena kurangnya kedekatan anak dengan ibu. Studi yang dilakukan oleh Vandel pada tahun 2004 diperoleh hasil bahwa, ketika anak lebih banyak menghabiskan waktu di tempat penitipan pada usia awal, maka anak akan mengalami interaksi yang kurang sensitif dengan ibunya. Anak akan memiliki masalah perilaku. ${ }^{6}$

Faktor lain yang memungkinkan kurangnya kelekatan antara ibu dan anak pada ibu bekerja yaitu pemberian susu formula atau makanan lain selain ASI sebelum anak usia 6 bulan. Ibu bekerja yang memiliki penghasilan tinggi berpeluang mempunyai daya beli yang tinggi juga, termasuk daya beli terhadap susu formula. Penelitian Purnamawati tahun 2003 diperoleh hasil bahwa tingkat sosial ekonomi ibu merupakan faktor yang paling dominan terhadap pemberian ASI eksklusif. Ibu dengan tingkat sosial ekonomi rendah mempunyai peluang sebesar 4,6 kali untuk menyusui secara eksklusif dibandingkan dengan ibu dengan tingkat sosial ekonomi tinggi. ${ }^{22}$

Berat badan lahir anak dan umur kehamilan tidak mempengaruhi mental emosional anak, namun demikian prosentase anak yang lahir dengan berat badan $<2500$ gr dan mempunyai masalah mental emosional lebih banyak $(71,4 \%)$ dibandingkan dengan anak yang lahir dengan berat badan $\geq(41,6 \%)$. Riksani menyatakan bahwa anak yang lahir dengan berat badan kurang dan prematur mampu menyusu pada ibu meski belum kuat. Seiring bertambahnya berat badan dan umur anak, maka anak akan semakin kuat untuk menyusu pada ibu. ${ }^{3}$ Pendapat ini tidak sejalan dengan Soetjiningsih. Soetjiningsih menyatakan bahwa anak yang lahir prematur dan kurang bulan akan cenderung rewel sehingga lebih merepotkan ibu dan menimbulkan rasa tidak tenang. ${ }^{23}$ Rasa cemas akan mengurangi produksi ASI dan menimbulkan keengganan untuk menyusui sehingga akan mengurangi kelekatan antara ibu dengan anak. ${ }^{25}$

Pelaksanaan IMD juga tidak berpengaruh terhadap mental emosional anak. Anak yang lahir tanpa dilakukan IMD masih mempunyai kesempatan untuk disusui secara eksklusif. Faktor yang mempengaruhi dilakukannya IMD yaitu sikap dari penolong persalinan. . Hasil penelitian Fikawati dan Syafiq menunjukkan adanya hubungan yang signifikan antara bidan sebagai penolong bersalinan dengan IMD. Bidan yang mempunyai sikap positif terhadap IMD berpeluang lebih besar melakukan IMD dibandingkan dengan bidan yang mempunyai sikap negatif terhadap IMD. ${ }^{25}$

Penelitian ini memungkinkan terjadinya bias informasi atas kemampuan responden mengingat keadaan waktu lalu saat memiliki bayi usia 3-4 tahun.

\section{SIMPULAN}

Pemberian ASI, pengetahuan ibu, sikap ibu, dan tingkat pendidikan ibu merupakan faktor yang berpengaruh terhadap mental emosional anak.Pemberian ASI merupakan variabel yang paling berpengaruh terhadap mental emosional anak setelah dikontrol oleh pengetahuan ibu, sikap ibu, tingkat pendidikan ibu, dan berat badan lahir anak.

\section{DAFTAR PUSTAKA}

1. Kent, G. Chid feeding and human right. International Breastfeeding Journal. 2006;1:112. Avaliable from http://www.biomedcentral.com/content/pdf/17464358-1-27. Diakses pada tanggal 31 Mei 2013

2. Okeh. Breastfeeding And The Mother-Child relationship : A Case Study Of Ebonyi State University Teaching Hospital, Abakaliki, African 
Journal Of Primary Healt Care And Family Medicine (serial online).2010: 2: 1-3. Avaliable from

http://www.phcfm.org/index.php/phcfm/article/vie wFile/97/63. Diunduh pad tanggal 12 Maret 2013.

3. Riksani, R. Keajaiban ASI. Jakarta. Dunia Sehat; 2012

4. Departemen Pendidikan Nasional. Membangun sosial emosional anak di usia 0-2 tahun. Jakarta; 2011

5. Damayanti,R. Pengaruh terapi kelompok terapeutik terhadap kemampuan ibu dalam memberikan stimulasi perkembangan inisiatif anak usia pra sekolah di Kelurahan Kedaung Bandar Lampung [tesis]. Universitas Indonesia: Depok; 2011

6. Santrock, W. Perkembangan anak. Jakarta: Penerbit Erlangga; 2007

7. Goleman, D. Emotional intelligence. Jakarta: Gramedia Pustaka Utama; 1999

8. McGue, Iacono W. The association of early adolescent problem behavior with adult psychopathology. Psychiatry. 2005;162:11181124. Avaliable from http://ajp. psychiatryonline.org/data/Journals/AJP/4009/1118. pdf. Diakses pada tanggal 4 Nopember 2013

9. Badan Penelitian dan Pengembangan Kementrian Kesehatan RI. Riset kesehatan dasar (Riskesdas) 2013. Jakarta; 2013

10. Puskominfo POLDA Metro Jaya. Kasus kriminal dilakukan oleh anak-anak. Jakarta; 2008 Terdapat dalam

http://humaspoldametrojaya.blogspot.com/2012/05 /2.html. Diakses pada tanggal 6 September 2014

11. Mende, L. Preschooler emotional understanding of others who are ethically the same or different. [thesis]. University of Maryland; 2004

12. Kramer M, Fombonne E, Igumnov S, Vanilovich I, Matush L, Mironova E, et al. Effects of prolonged and exclusif breastfeeding on child behaviour and mathernal adjustment: Evidence from a large, randomized trial. Paediatric. 2008;121:1-8. Avaliable from http://pediatrics.aappublications.org/content/121/3/ e435.full.pdf + html Diunduh pada tanggal 15 Nopember 2013

13. Dinas Kesehatan Kota Semarang. Profil kesehatan Kota Semarang. Semarang; 2010

14. Dinas Kesehatan Kota Semarang. Profil kesehatan Kota Semarang. Semarang; 2011

15. Eisemann M, Brondbo PH, Mathiessen B. The ability of the strength and difficulties questionnare to detect mental health disorder in a child and adolesent outpatient clinic in Northern-Norwey [tesis]. Norwey: I Tromso Universitetet; 2010

16. Ambarwati, Ria. Pengaruh konseling laktasi yang intensif terhadap pemberian air susu ibu (ASI) eksklusif sampai dengan bayi berumur 3 bulan. [tesis]. Semarang: Universitas Diponegoro; 2011

17. Fauzie, R. Pola menyusui pada ibu pekerja di beberapa wilayah di Jakarta dan faktor-faktor yang dapat mempengaruhinya [tesis]. Depok: Universitas Indonesia; 2006

18. Afriana, N.Analisis praktek pemberian ASI eksklusif oleh ibu bekerja di instansi pemerintah DKI Jakarta [tesis]. Depok: Universitas Indonesia; 2004

19. Nooatmodjo Soekidjo. Pendidikan dan perilaku kesehatan. Jakarta: Rineka Cipta; 2003

20. Ida, Faktor-faktor yang berhubungan dengan pemberian ASI eksklusif 6 bulan di wilayah kerja Puskesmas Kemiri Muka Kota Depok Tahun 2011 [tesis]. Universitas Indonesia. Depok; 2012

21. Inayah, Giri, Determinan pemberian ASI eksklusif pada ibu bekerja di kementrian kesehatan RI tahun 2012 [tesis]. Depok: Universitas Indonesia; 2012

22. Purnamawati, S. Faktor-faktor yang berhubungan dengan pola pemberian ASI pada bayi usiaempat bulan. Jakarta: Media Litbang Kesehatan; 2003:XIII:3:29-37

23. Soetjiningsih. Tumbuh kembang anak. Surabaya : EGC ; 1995

24. King, F Savage. Menolong ibu menyusui, pedoman praktis bagi para ibu dan petugas kesehatan. Jakarta: Gramedia Pustaka Utama; 1991

25. Fikawati S, Syafiq A. Kajian Implementasi Air Susu Ibu Eksklusif dan Inisiasi Menyusu Dini. Makara Kesehatan; 2010: 14: 1: 17-24 